\title{
POLITIK HUKUM PENGELOLAAN HULU MIGAS PASCA PUTUSAN MAHKAMAH KONSTITUSI
}

\section{(Politics of Law of Upstream Oil and Gas Management after the Constitutional Court Decision)}

\author{
M. Ilham F Putuhena \\ Pusat Perencanaan Pembangunan Hukum Nasional \\ Badan Pembinaan Hukum Nasional \\ Jl Mayjen Soetoyo No 10, Cililitan, Jakarta Timur \\ Email: ilham.bphn@gmail.com
}

Naskah diterima: 15 Juni 2015; revisi: 10 Agustus 2015; disetujui: 19 Agustus 2015

\begin{abstract}
Abstrak
Putusan Mahkamah Konstitusi Nomor 36/PUU-X/2012 dalam permohonan Pengujian Undang-Undang Nomor 22 Tahun 2001 tentang Minyak dan Gas Bumi terhadap Undang-Undang Dasar Negara Republik Indonesia Tahun 1945 telah membawa arah baru di dalam pengelolaan hulu migas di Indonesia. Mahkamah Konstitusi berpendapat model hubungan BPMigas dalam melakukan pengelolaan Migas telah mendegradasi makna penguasaan negara atas sumber daya alam Migas sebagaimana diamanatkan Pasal 33 UUD NRI Tahun 1945. Berangkat dari kondisi tersebut beberapa hal yang menarik untuk diteliti, yaitu bagaimana arah politik hukum pengelolaan hulu migas pasca putusan Mahkamah Konstitusi, kemudian dilanjutkan terhadap pembahasan alternatif model pengelolaan hulu migas yang sesuai dengan konstitusional. Guna menjawab permasalahan tersebut penelitian ini menggunakan metode penelitian yuridis Normatif, yang meneliti pengaturan hulu Migas dibandingkan dengan putusan Mahkamah Konstitusi, dan kemudian dijadikan dasar untuk menentukan alternatif arah politik hukum hulu migas yang baru. Dari hasil penelitian didapat sedikitnya empat alternatif model kelembagaan pengelolaan hulu Migas yaitu: model melembagakan SKK Migas secara permanen; model yang memberikan wewenang kembali kepada PERTAMINA; model pemerintah secara langsung melakukan penunjukan, dan mendirikan BUMN baru atau model dengan pembentukan lembaga baru. Dari penelitian ini disarankan Pemerintah dan DPR harus menjadikan putusan mahkamah konstitusi sebagai bahan acuan dalam mendesain model pengelolaan hulu Migas, dapat menghasilkan kelembagaan dan pengelolaan yang konstitusional dalam rangka membangun kepastian berinvestasi dalam bisnis Migas di Indonesia.

Kata Kunci: politik hukum, pengelolaan hulu migas, putusan Mahkamah Konstitusi
\end{abstract}

\begin{abstract}
Constitutional Court Decision No. 36/PUU-X / 2012 in a petition for judicial review of Law No. 22 of 2001 on Oil and Gas against the Constitution of the Republic of Indonesia Year 1945 has brought a new direction in the management of upstream oil and gas in Indonesia. The Constitutional Court argued that BPMigas business relationship model in managing oil and gas has been degrading the meaning of state control over natural resources of oil and gas as mandated by the Article 33 of the 1945 Constitution. Departing from these conditions some interesting things to be investigated, are how the politics of law direction of the upstream oil and gas management after the Constitutional Court decision, and then followed by the discussion of alternative models of upstream oil and gas management that is in accordance with constitutional. To answer these problems this research is using normative juridical method, which examined the setting of upstream oil and gas compared with the Constitutional Court decision, which is then being used as the basis for determining the alternative direction of politics of law of the new upstream oil and gas laws. The result is at least four alternative models of institutional management of upstream oil and gas obtained, namely: a model where it institutes SKK Migas permanently; a model that gives authority back to Pertamina; a model where the government make direct appointment, and established new state-owned enterprises or a model with the establishment of new institutions. What this research suggested is that the Government and Parliament must make Constitutional Court decision as a reference in designing the management model of the upstream oil and gas, where it can produce institutional and constitutional governance in order to establish certainty to invest in oil and gas business di Indonesia.
\end{abstract}

Keywords: politics of law, management of oil and gas upstream, Constitutional Court decision 


\section{A. Pendahuluan}

Pengelolaan minyak dan gas (Migas) bumi saat ini masih memainkan peranan penting untuk menunjang kesinambungan pembangunan Indonesia, baik sebagai salah satu andalan utama penghasil devisa juga sebagai pemasok kebutuhan energi dalam negeri yang berpengaruh terhadap ekonomi nasional. Besarnya pengaruh tersebut sehingga Migas dapat dinyatakan sebagai aspek penting dari potensi bangsa.

Sejarah kemerdekaan bangsa dan negara Indonesia mencatat bahwa kemerdekaan yang diraih oleh rakyat Indonesia adalah hasil perjuangan seluruh komponen bangsa dan sama sekali bukan pemberian dari pihak lain. Perjuangan rakyat tersebut merupakan suatu usaha dengan pengorbanan yang tak ternilai harganya dengan satu cita-cita untuk dapat bersama-sama menjadi suatu bangsa yang bebas dan merdeka dari penjajahan bangsa lain. Dengan bekal kemerdekaan yang telah diperolehnya, sebagaimana tersurat dalam pembukaan Undang-Undang Dasar Negara Republik Indonesia Tahun 1945 (UUD NRI Tahun 1945), dibentuklah suatu pemerintahan negara Indonesia yang bertujuan salah satunya untuk memajukan kesejahteraan umum dengan berdasarkan kepada keadilan sosial bagi seluruh rakyat Indonesia. Migas sebagai salah satu aset negara tentu mempunyai nilai yang penting dalam memberikan manfaat besar bagi negara khususnya Rakyat Indonesia.
Dalam rangka memajukan kesejahteraan dan membangun keadilan sosial tersebut maka salah satu prinsip pengelolaan negara dicantumkan dalam Pasal 33 ayat (3) UUD NRI Tahun 1945 dengan menyatakan: "Bumi dan air dan kekayaan alam yang terkandung di dalamnya dikuasai oleh negara dan dipergunakan sebesar-besarnya untuk kemakmuran rakyat." Mahkamah Konstitusi, ${ }^{1}$ dalam putusan Nomor 3/PUU-VIII/2010, tanggal 16 Juni 2011, mempertimbangkan bahwa, “...dengan adanya anak kalimat "dipergunakan untuk sebesarbesar kemakmuran rakyat" maka sebesar-besar kemakmuran rakyat itulah yang menjadi ukuran bagi negara dalam menentukan tindakan pengurusan, pengaturan, atau pengelolaan atas bumi, air dan kekayaan alam yang terkandung di dalamnya..." (vide paragraf [3.15.4] hal. 158 putusan Mahkamah Nomor 3/PUU-VIII/2010).

Apabila penguasaan negara tidak dikaitkan secara langsung dan satu kesatuan dengan sebesar-besar kemakmuran rakyat maka dapat memberikan makna konstitusional yang tidak tepat. Artinya, negara sangat mungkin melakukan penguasaan terhadap sumber daya alam secara penuh tetapi tidak memberikan manfaat sebesar-besar kemakmuran rakyat. Di satu sisi negara dapat menunjukkan kedaulatan pada sumber daya alam, namun di sisi lain rakyat tidak serta merta mendapatkan sebesar-besar kemakmuran atas sumber daya alam. Oleh karena itu, menurut Mahkamah, kriteria konstitusional untuk mengukur makna 
konstitusional dari penguasaan negara justru terdapat pada frasa "untuk sebesar-besar kemakmuran rakyat". Migas sebagai kekayaan alam yang terkandung didalam bumi Indonesia menjadi salah satu fokus yang penting untuk dikaji khususnya mengenai pengelolaannya terhadap Blok Migas yang telah dikelola dan akan dikelola, salah satu issu yang sangat penting dibahas adalah bagaimana model hubungan negara dan swasta dalam pengelolaan blok migas tersebut dan bagaimanakah hubungan tersebut dibangun. sentasi negara dengan badan usaha atau bentuk usaha tetap dalam pengelolaan Migas mendegradasi makna penguasaan negara atas sumber daya alam Migas yang bertentangan dengan amanat Pasal 33 UUD NRI Tahun 1945. Walaupun UU Migas, menentukan tiga syarat minimal dalam Kontrak Kerja Sama, yakni i) kepemilikan sumber daya alam di tangan Pemerintah sampai pada titik penyerahan, ii) pengendalian manajemen operasi berada pada BP Migas, dan iii) modal dan resiko seluruhnya ditanggung Badan Usaha atau Bentuk Usaha Tetap, tetapi ketiga

Tabel

Potensi Minyak dan Gas di Indonesia²

Peta Cadangan Migas

Oil Reserves (MMstb)

Proven (P1) $=3.624$

Potential $(\mathrm{P} 2+\mathrm{P3})=3.751$

Total (3P) $\quad=7.375$

Gas Reserves (Tsef)

Proven (PI) $\quad=100$

Potential $(\mathrm{P} 2+\mathrm{P3})=49$

Total $(3 P)=149$

Belajar pembubaran Badan Pelaksana Migas (BP Migas) yeng mengurus mengenai pengelolaan hulu Migas di Indonesia yang kemudian dinyatakan oleh Mahkamah Konstitusi bertentangan dengan UUD NRI Tahun 1945, dengan putusan Nomor 36/PUU-X/2012 pengujian atas Undang-Undang 22 Tahun 2001 Tentang Minyak dan Gas Bumi (UU Migas). Menurut Mahkamah model hubungan antara BP Migas sebagai repre- syarat minimal tersebut tidak serta merta berarti bahwa penguasaan negara dapat dilakukan dengan efektif untuk sebesar-besar kemakmuran rakyat.

Ada tiga hal yang dianggap oleh mahkamah konstitusi bahwa BP Migas inkonstitusional, yaitu: Pertama, Pemerintah tidak dapat secara langsung melakukan pengelolaan atau menunjuk secara langsung badan usaha milik

Lihat Laporan Tahunan SKK Migas 2014. hlm 18. 
negara untuk mengelola seluruh wilayah kerja Migas dalam kegiatan usaha hulu; Kedua, setelah BP Migas menandatangani KKS, maka seketika itu pula negara terikat pada seluruh isi KKS, yang berarti, negara kehilangan kebebasannya untuk melakukan regulasi atau kebijakan yang bertentangan dengan isi KKS; Ketiga, tidak maksimalnya keuntungan negara untuk sebesar besar kemakmuran rakyat, karena adanya potensi penguasaan Migas keuntungan besar oleh Bentuk Hukum Tetap atau Badan Hukum Swasta yang dilakukan berdasarkan prinsip persaingan usaha yang sehat, wajar dan transparan. Dengan konstruksi penguasaan Migas melalui BP Migas, negara kehilangan kewenangannya untuk melakukan pengelolaan atau menunjuk secara langsung Badan Usaha Milik Negara untuk mengelola sumber daya alam Migas, padahal fungsi pengelolaan adalah bentuk penguasaan negara pada peringkat pertama dan paling utama untuk mencapai sebesar-besar kemakmuran rakyat.

Sejak putusan Mahkamah Konstitusi Nomor 36/PUU-X/2012 yang telah menetapkan inkonstitusionalitas BP Migas dan menekankan model hubungan baru dalam pengelolaan Migas di Indonesia sampai saat ini belum ada undangundang baru yang mengatur pola pengelolaan Migas. Walaupun sejak 2013 hingga kini agenda Revisi UU Migas telah digulirkan baik Masuk Program Legislasi Nasional (Prolegnas) tetapi belum ada kejelasan pembahasan revisi UU Migas tersebut, padahal dari segi substansi perlu segera kejelasan dalam pengaturan pengelolaan hulu migas di Indonesia. Salah satu tantang yang akan segera harus disikapi adalah berakhirnya KKS beberapa Blok Migas.
Untuk blok Migas yang akan berakhir 2015 telah tentukan pengelolanya, seperti Blok Pase yang dikelola sementara oleh PT Triangle Pase Inc (TPI). Kementerian Energi dan Sumber daya Mineral (ESDM) juga memberikan hak pengelolaan kepada Badan Usaha Milik Daerah (BUMD) PT Perusahaan Daerah Pembangunan Aceh (PDPA). PT TPI diputuskan untuk menjadi mitra sebagai operator. Tapi, hak pengelolaan masih dipegang BUMD. Blok Kampar, Riau, sebelumnya ditangani Medco E\&P. Wilayah Kerja (WK) diserahkan kepada PT Pertamina (Persero) dengan masa transisi sampai Desember 2015. Blok Gebang, hak pengelolaan oleh PT Energi Mega Persada (EMP). Sebab, pengelola saat ini, Pertamina dan Costa International Grup, tidak mengajukan permohonan perpanjangan kepada pemerintah. Blok Offshore Northwest Java (ONWJ) diberikan perpanjangan kepada Pertamina. Dengan syarat agar komposisi saham partisipasi ( $\mathrm{Pl} /$ participating interest) lebih besar.

Kemudian pengelolaan Blok Mahakam dengan Kontraktor Kontrak Kerja Sama (KKKS) yaitu Total E\&P Indonesie dan Inpex Corporation, kontrak bagi hasil blok Mahakam ditandatangani tahun 1967, kemudian diperpanjang pada tahun 1997 untuk jangka waktu 20 tahun sampai tahun 2017, Cadangan (gabungan cadangan terbukti dan cadangan potensial atau dikenal dengan istilah 2P) awal yang ditemukan saat itu sebesar 1,68 miliar barel minyak dan gas bumi sebesar 21,2 triliun kaki kubik (TCF). Dari penemuan itu maka blok tersebut mulai diproduksikan dari lapangan Bekapai pada tahun $1974 .^{3}$

Dan dari kajian Pusat Hukum Energi dan Pertambangan (PUSHEP) maka terdapat 23 
Blokmigas yang akan berkahir kontraknya mulai 2018-2021, yaitu: ${ }^{4}$

1. Kontrak Berakhir Tahun 2018

Blok Tuban (JOB Pertamina-Petrochina), Blok Ogan Komering (JOB PertaminaTalisman), North Sumatera Offshore /NSO B Block (Exxon Mobil), Southeast Sumatera (CNOOC), Blok Tengah (Total), Blok NSO-NSO (Aceh Extent Exxon Mobil), Blok Sanga-Sanga, Kalimantan Timur (VICO), Blok W.Pasir dan Attaka (Chevron Indonesia Company).

2. Kontrak yang berakhir 2019

Blok Bula (Kalrez Petroleum), Seram-Non Bula Block (Citic), Blok Pendaopo dan Raja (JOB Pertamina-Golden Spike), Blok Jambi Merang (JOB Pertamina-HESS).

3. Kontrak yang Habis 2020

Blok South Jambi B (Conoco Phillips), Blok Selat Malaka (Kondur Petroleum), Blok Brantas (dikelola Lapindo), Blok Salawati, (JOB Pertamina-Petrochina), Blok Kepala Burung $A$ (Petrochina International Bermuda), Blok Sengkang, (Energy Equity), Blok Makassar Strait Offshore Area A (Chevron Indonesia Company).
4. Kontrak yang berakhir 2021

Blok Rokan (Chevron Pacific Indonesia), Blok Bentu Segat (Kalila), Blok Muriah (Petronas), Blok Selat Panjang (Petroselat).

Darikondisiyang ada danarah perkembangan politik hukum yang ada, masih memberikan beberapa pola hubungan yang harus dipertegas dalam penataan kelembagaan dan model hubungan pemerintah dengan swasta yang akan menjadi operator dalam pengelolaan Hulu Migas. Untuk itu alternatif kebijakan mengenai model pengelolaan Hulu Migas penting untuk dimunculkan sebagai pertimbangan dan pencarian dalam memilih yang manakah pola yang lebih tepat dengan kondisi Indonesia saat ini, sehingga dengan memilih dari beberapa alternatif pola pengelolaan hulu Migas akan lebih menjamin konstitusionalitas pengaturan yang akan meningkatkan kepastian hukum dalam bisnis Hulu Migas di Indonesia.

Kegiatan usaha Hulu Migas merupakan kegiatan yang memiliki High Cost dan High Risks, ${ }^{5}$ yang terdiri atas kegiatan eksplorasi yang bertujuan memperoleh informasi mengenai kondisi geologi untuk menemukan dan memperoleh perkiraan cadangan Migas

\footnotetext{
Lihat, http://www.pushep.or.id/view_publikasi.php?id=12\#.VX0wI5Nq9_k. Kepastian Hukum Terhadap Kontrak Blok-Blok Migas yang Akan Berakhir, Terakhir diakses 9 Juni 2015.Jangka Waktu dan Kondisi Perpanjangan Kontrak Jangka waktu kontrak kerja sama dilaksanakan paling lama 30 (tiga puluh) tahun. Badan usaha atau bentuk usaha tetap dapat mengajukan perpanjangan jangka waktu kontrak kerja sama paling lama 20 (dua puluh) tahun. Jangka waktu kontrak kerja sama terdiri atas jangka waktu eksplorasi dan eksploitasi. Jangka waktu eksplorasi dilaksanakan 6 (enam) tahun dan dapat diperpanjang hanya 1 (satu) kali periode yang dilaksanakan paling lama 4 (empat) tahun. Lihat: Pasal 14 dan 15 Undang-Undang no 22 Tahun 2001 tentang Minyak dan Gas Bumi.

5 Industri Migas merupakan satu industri yang memiliki resiko yang tinggi (high risk), penggunaan teknologi canggih (high technology), dan sumber daya yang terlatih serta besarnya capital yang diperlukan (high capital). Paling tidak ada empat faktor yang membuat industri hulu migas berbeda dengan industri lainnya, antara lain: pertama, lamanya waktu antara saat terjadinya pengeluaran (expenditure) dengan pendapatan (revenue). Kedua, keputusan yang dibuat berdasarkan risiko dan ketidakpastian tinggi serta melibatkan teknologi canggih. Ketiga, sektor ini memerlukan investasi biaya capital yang relatif besar. Keempat, dibalik semua resiko tersebut, industri migas juga menjanjikan keuntungan yang sangat besar. Benny Lubiantara, Ekonomi Migas Tinjauan Aspek Komersial Kontrak Migas. (Jakarta: Gramedia Widiasarana Indonesia, 2012), hlm 5.
} 
di wilayah kerja yang ditentukan, dan kegiatan eksploitasi sebagai rangkaian kegiatan yang bertujuan untuk memproduksi Migas yang terdiri atas pengeboran dan penyelesaian sumur, pembangunan sarana pengangkutan, penyimpanan, dan pengolahan untuk pemisahan dan pemurnian minyak dan gas bumi di lapangan serta kegiatan lain yang mendukungnya. Besarnya biaya dan resiko tersebut menuntut besar pula kepastian hukum oleh negara. Dengan kondisi tersebut maka penulis menganggap penting untuk melakukan kajian tentang aspek pengelolaan Hulu Migas ditinjau dari aspek hukum.

Berdasarkan uraian tersebut diatas maka, terdapat beberapa hal yang perlu untuk dikaji, yaitu Bagaimanakah arah politik hukum baru pengelolaan Hulu Migas pasca putusan Mahkamah Konstitusi? Kemudian apa alternatif model pengelolaan Hulu Migas dengan politik hukum baru tersebut sehingga tidak bermasalah secara konstitusional.

\section{B. Metode Penelitian}

Penelitian ini menggunakan metode penelitian yuridis Normatif, ${ }^{6}$ dimana Data diperoleh dari studi kepustakaan akan dianalisis secara deskriptif kualitatif. Analisis deskriptif kualitatif yaitu metode analisis data yang mengelompokkan dan menyeleksi data yang diperoleh menurut kualitas dan kebenarannya, kemudian dihubungkan dengan teori-teori, asas-asas, dan kaidah-kaidah hukum yang diperoleh dari studi kepustakaan sehingga diperoleh jawaban atas permasalahan yang dirumuskan. Dalam kajian ini maka kajian akan diarahkan melihat bagaimana pengaturan dalam UU Migas, kemudian melihat Putusan Mahkamah Konstitusi yang kemudian akan menjadi landasan dalam menentukan alternatif politik hukum pengelolaan hulu Migas.

\section{Pembahasan}

\section{Arah Politik Hukum Baru Pengelolaan Hulu Migas Pasca Putusan Mahkamah Konstitusi}

Sebagai negara modern maka Indonesia dalam konstitusi atau UUD NRI Tahun 1945 telah berprinsip sebagai negara demokrasi dan negara hukum yang bertujuan untuk membangun kesejahteraan bagi rakyatnya. ${ }^{7}$ 
Sehingga Ada 2 (dua) landasan pokok yang harus menjadi pilar dalam pelaksanaan Pembangunan Hukum Nasional, yaitu: ${ }^{8}$

a. Landasan Idiil yang merupakan norma dasar kehidupan berbangsa dan bernegara, yaitu hukum yang berwatak Pancasila.

b. Landasan Operasional, yaitu:

1) Hukum yang adil dan mensejahterakan.

2) Hukum yang memperkuat demokrasi.

3) Hukum yang melindungi HAM.

4) Hukum yang memperkukuh NKRI.

5) Hukum yang berbhineka tunggal ika.

6) Hukum yang melindungi bangsa dan tumpah darah Indonesia.

Landasan pokok tersebut hendaknya menjadi dasar dalam pelaksanaan Politik Hukum Nasional. karena politik hukum sangat menentukan arah kebijakan pembangunan nasional secara keseluruhan yang akan dilaksanakan dalam suatu periode tertentu. Politik hukum pada dasarnya merupakan pemikiran yang menjadi dasar campur tangan negara melalui alat perlengkapan negara (pemerintah, DPR, dan sebagainya) pada hukum. Campur tangan negara dengan alat perlengkapannya pada hukum, dalam hal: ${ }^{9}$ a. Penciptaan Hukum:

Negara berkewajiban memelihara keadilan dan ketertiban. Untuk memelihara keadilan dan ketertiban tersebut negara menciptakan hukum.

b. Pelaksanaan Hukum:

Negara berkewajiban mengadakan alatalat perlengkapan negara yang bertugas melaksanakan atau menegakkan hukum menurut cara tertentu yang ditentukan oleh negara, antara lain melalui pengadilan.

c. Perkembangan Hukum:

Hukum disusun berdasarkan kesadaran hukum masyarakat. Negara berusaha mempengaruhi perkembangan kesadaran hukum masyarakat, sehingga negara mempengaruhi perkembangan hukum.

Sehingga dari gambaran tersebut proses Legislasi menjadi pintu utama dalam menjalankan politik hukum ${ }^{10}$ nasional walaupun tidak mengenyampingkan pembentukan hukum lain diluar proses legislasi, Sebagai negara yang menjunjung tinggi Hukum (Nomokrasi) dan Demokrasi dalam penyelenggaraan negara. Peran legislasi ini dimiliki oleh DPR, dan dibahas bersama Pemerintah.

susunan Negara Republik Indonesia yang berkedaulatan rakyat dengan berdasar kepada Ketuhanan Yang Maha Esa, Kemanusiaan yang adil dan beradab, Persatuan Indonesia dan Kerakyatan yang dipimpin oleh hikmat kebijaksanaan dalam Permusyawaratan/Perwakilan, serta dengan mewujudkan suatu Keadilan sosial bagi seluruh rakyat Indonesia.

8 Badan Pembinaan Hukum Nasional, Perencanaan Pembangunan Hukum Nasional 2015-2019, (Jakarta: Pusat Perencanaan Pembangunan Hukum Nasional, BPHN, 2012), hlm. 56.

$9 \quad$ Ibid, hlm. 67.

10 Mahfud M.D. mendefinisikan politik hukum sebagai legal policy yang akan atau telah dilaksanakan secara nasional oleh pemerintah Indonesia yang meliputi: pertama, pembangunan hukum yang berintikan pembuatan dan pembaruan terhadap materi-materi hukum agar dapat sesuai dengan kebutuhan; kedua, pelaksanaan ketentuan hukum yang telah ada termasuk penegasan fungsi lembaga dan pembinaan para penegak hukum. Dari pengertian itu, terlihat politik hukum mencakup proses pembuatan dan pelaksanaan hukum yang dapat menunjukkan sifat dan ke arah mana hukum akan dibangun dan ditegakkan. Mahfud.M.D., Politik Hukum di Indonesia, edisi revisi. Cetakan pertama, (Jakarta: Rajawali Pers, 2009) hlm.1. 
Perkembangan pengaturan tentang pengelolaan Migas sejak kemerdekaan hingga sekarang ini, dimulai dengan Undang-undang Nomor 44 Prp Tahun 1960 Tentang Pertambangan Minyak Dan Gas Bumi, Bentuk kerja sama pengelolaan sumber daya Migas dalam bentuk Kontrak Karya. Pengesahan perjanjian Kontrak Karya melalui Undang- undang. Hasil atas minyak dan gas bumi berada ditangan Negara, namun aset yang dibeli oleh kontraktor untuk keperluan pelaksanaan pengusahaan migas tersebut menjadi milik kontraktor sampai berakhirnya masa penyusutan. Selain itu manajemen pelaksanaan berada di tangan kontraktor, dimana negara hanya mempunyai akses yang kecil untuk mengetahui atau menentukan jalannya operasi. ${ }^{11}$

Kemudian dilakukan perubahan dengan membentuk peraturan baru yaitu UndangUndang Nomor 8 Tahun 1971 tentang
Perusahaan Pertambangan Minyak dan Gas Bumi Negara (UU Pertamina), aturan ini memberikan wewenang yang sangat luas bagi PERTAMINA. mengemban amanat Pasal 33 UUD NRI 1945 dengan optimal. Dalam sektor hulu, operasi pelaksanaan pengusahaan pertambangan migas khususnya kegiatan eksplorasi dan eksploitasi, PERTAMINA bekerja sama dengan pihak asing dalam perjanjian dengan model Production Sharing Contract (PSC). ${ }^{12}$

Prinsip-prinsip kerjasama dalam Production Sharing Contract adalah PERTAMINA bertanggung jawab atas manajemen operasi, Kontraktor menyediakan seluruh dana dan teknologi yang dibutuhkan dalam operasi perminyakan, Kontraktor menanggung biaya dan resiko operasi, Kontraktor akan memperoleh kembali seluruh biaya operasi setelah produksi komersial (cost recovery), ${ }^{13}$ Hasil produksi

11 Untuk melakukan usaha pertambangan minyak dan gas bumi, maka negara mendirikan perusahaan negara. Kewenangan untuk melakukan usaha pertambangan minyak dan gas bumi tersebut diberikan oleh Negara kepada perusahaan negara (Pertamina). Jadi hanya Pertaminalah yang memiliki kewenangan untuk melakukan usaha pertambangan minyak dan gas bumi. Dengan kata lain Pertamina adalah pemegang kuasa pertambangan Migas. M.Kholid Syeirazi, Di Bawah Bendera Asing: Liberalisasi Industri Migas di Indonesia, Cetakan Pertama (Jakarta: LP3ES, 2009), hlm. 93.

12 Secara umum bentuk kerjasama yang mengatur hubungan negara dan swasta atau kontraktor dikategorikan dalam 5 jenis yaitu, Konsesi (consesion). Kontrak production Sharing (Production Sharing Contract), Kontrak Jasa Resiko (risk Service Contract), Kontrak Service (Service Contract), Usaha Patungan (Joint Venture). Daniel Johnston, International Potreleum fiscal system and production Sharing Contract, (Oklahoma: Price Waterhouse Publishing 1994, hlm 21. Kontrak bagi hasil (production sharing contract) di Indonesia mulai populer sejak pertama kali diperkenalkan pada 1960 di Venezuela oleh Ibnu Sutowo. Ibnu Sutowo memperkenalkan production sharing contract dengan pemikiran bahwa Indonesia pada saat itu merupakan Negara yang memiliki kandungan minyak dan gas bumi yang melimpah, tetapi Indonesia tidak memiliki kemampuan finansial yang kuat untuk melakukan investasi dalam kegiatan usaha hulu minyak dan gas bumi. Selain itu Indonesia pada saat itu tidak memiliki teknologi yang memadai untuk melakukan kegiatan usaha hulu minyak dan gas ini, dan yang terakhir Indonesia tidak memiliki tenaga kerja yang kompeten untuk melakukan kegiatan usaha hulu ini. Lihat: Rudi M. Simamora, Hukum Minyak dan Gas Bumi,(, Jakarta: Jambatan,2000), hlm. 93.

13 Cost Recovery adalah pengembalian biaya eksplorasi dan ekspoitasi migas dari Pemerintah kepada Kontraktor Kontrak Kerja Sama (KKKS). Cost recovery tersebut dibayarkan dalam bentuk produksi migas, yang dinilai dengan Weighted Average Price (WAP), yaitu harga rata-rata tertimbang dihitung berdasarkan nilai lifting selama satu tahun dibagi dengan jumlah satuan lifting selama periode yang sama. Abdul Nasir, Sejarah Sistem Fiskal Migas Indonesia, (Jakarta: Grasindo, 2014) Hlm 78. Cost Recovery sejatinya merupakan bagian dari hak dan kewajiban para pihak yang dimasukkan dalam perjanjian utama atau consideration. Afifah Kusumadara, Kontrak Bisnis Internasional, (Jakarta, Sinar Grafika, 2013), hlm. 2. 
setelah dikurangi biaya operasi dibagi antara negara dan kontraktor (bagi hasil), Kontraktor wajib mengembalikan sebagian wilayah kerjanya kepada Negara (relinquishment), Seluruh barang operasi yang dibeli kontraktor menjadi aset PERTAMINA setelah tiba di wilayah pabean Indonesia, Kepemilikan atas minyak yang dihasilkan berada di tangan negara, Kontraktor wajib membayar pajak penghasilan langsung kepada pemerintah Indonesia, Kontraktor wajib menyisihkan sebagian hak dari bagian bagi hasil migasnya untuk memenuhi kebutuhan migas dalam negeri Indonesia (DMO/Domestic Market Obligation). ${ }^{14}$

PSC sendiri mengalami beberapa kali perubahan, menyesuaikan dengan situasi dan kondisi industri. Adapun perubahannya adalah sebagai berikut: ${ }^{15}$

a. Tahun 1966, PSC generasi pertama di mana terdapat batasan $40 \%$ cost recovery, Pembagian hasil produksi antara Pemerintah dan Kontraktor sebesar 65:35 dan untuk produksi diatas 75,000 barrel per hari sebesar 67.5:32.5, 25\% DMO dengan harga pasar (ICP) untuk 60 bulan pertama, dan selanjutnya dihargai $\$ 0.20$ per barrel.

b. Tahun 1976, PSC generasi kedua, terjadi perubahan dimana jaminan 100\% cost recovery, tidak ada batasan. Pembagian hasil produksi antara Pemerintah dan Kontraktor sebesar 85:15. 25\% DMO dengan harga pasar (ICP) untuk 60 bulan pertama, dan selanjutnya dihargai $\$ 0.20$ per barrel. $20 \%$ Investment Credit. Tahun 1978, dilakukan perubahan pada pasal 267 UU Pertamina tentang PSC, Tarif pajak menjadi efektif
$56 \%$, terdiri dari $45 \%$ untuk Net Income dan $20 \%$ untuk deviden yaitu keuntungan setelah pajak. Pembagian hasil produksi antara Pemerintah dan Kontraktor sebesar 85:15. Pembagian sebelum pajak sebesar $65.9091 \%$ dan $34.0909 \%$, dimana setelah pajak menjadi 85:15.

c. Tahun 1988, Pemerintah menetapkan peraturan perundang-undangan perpajakan pada tahun 1984. Pajak baru untuk production sharing contract tarif 48 persen, namun peraturan tersebut baru dapat diterapkan terhadap kontrak yang ditandatangani pada tahun 1988 karena dalam perundingan yang dilakukan, pihak kontraktor mempunyai kecenderungan untuk menggunakan peraturan perpajakan yang lama. Dengan demikian pembagian hasil berubah menjadi $71,15 \%$ untuk Pertamina dan 28,85\% untuk kontraktor (minyak), serta $42,31 \%$ untuk Pertamina dan 57,69\% untuk kontraktor (gas). Akan tetapi setelah dikurangi pajak, komposisi pembagian hasilnya masing-masing pihak Adalah 65 persen untuk Pertamina dan 35\% untuk kontraktor (minyak), serta $70 \%$ untuk Pertamina dan 30\% untuk kontraktor (gas). Kemudian dalam Peraturan Pemerintah Nomor 35 Tahun 1994 Syarat-Syarat Dan Pedoman Kerja Sama Kontrak, Bagi Hasil Minyak Dan Gas Bumi. Besaran pajak berubah dari $48 \%$ menjadi $44 \%$ yang terdiri dari $30 \%$ dan pajak dividen sebesar $14 \%$. Standar investment credit untuk keperluan cost recovery turun dari $17 \%$ menjadi $15.78 \%$. Skema bagi hasil sebelum pajak

14 Salim H. S, Hukum Pertambangan di Indonesia, (Jakarta:Rajagrafindo Persada, 2006), hlm. 266, 267 dan 273.

15 Ibid. 
juga berubah menjadi 73.22\%:26.78\%. DMO sebesar $25 \%$ dari milik kontraktor (15\% dari harga export setelah 5 tahun pertama produksi) Jangka Waktu Eksplorasi selama 6 tahun dan hanya dapat diperpanjang 1 kali selama 4 tahun, Komersialitas tidak diberi batasan minimum pendapatan pemerintah. Sebelum melakukan kegiatannya Kontraktor diwajibkan melakukan environmental base line study.

d. Production sharing contract 2002 sampai sekarang, DMO ditetapkan 25\%, perubahan pada generasi keempat ini merupakan imbas dari diberlakukannya UU Migas, sehingga kedudukan para pihak dari kontrak ini berubah. Pada generasi sebelumnya para pihak yang terlibat dalam kontrak adalah Pertamina dengan kontraktor, sedangkan pada generasi yang baru ini berubah menjadi Badan Pelaksana dengan badan usaha atau bentuk usaha tetap. Dalam kapasitasnya sebagai pemegang kuasa pertambangan Pemerintah Indonesia membentuk Badan Pelaksana Kegiatan Usaha Hulu Minyak dan Gas (BP MIGAS) untuk melakukan pengendalian dan pengelolaan kegiatan usaha hulu di bidang minyak dan gas bumi. Apabila pemerintah belum melaksanakan atau tidak dapat melaksanakan eksplorasi atau eksploitasi sendiri, maka Menteri Energi dan Sumber Daya Alam dapat menunjuk pihak lain sebagai kontraktor.

Munculnya undang- undang No 22 tahun 2001 tentang minyak dan gas bumi, sendiri tidak bisa dilepaskan dari dari paket Letter of Intent (Lol), yang dilakukan dengan International
Monetary Fund (IMF) dan World Bank, untuk meliberalisasi dan men-deregulasi sektorsektor strategis di Indonesia. ${ }^{16}$ Dengan adanya undang-undang otomatis menghilangkan peran Pertamina yang merupakan perusahaan negara dan sebagai satu-satunya pemegang kuasa pertambangan minyak dan gas bumi di Indonesia. Pertamina dibuat sebagai sama dengan kontraktor migas swasta di Indonesia. Pertamina dipisah antara pengurusan Migas hulu dan hilir. ${ }^{17}$

Dengan banyaknya isu atas tidakefisienan kinerja PERTAMINA, isu banyaknya kebocoran finansial, isu monopoli, sehingga timbul ide pembentukan sebuah perusahaan migas nasional yang bertaraf dunia yang mampu bersaing dengan perusahaan-perusahaan dari negara lain. Hal-hal inilah yang kemudian mendasari dikeluarkannya UU Migas tahun 2001.

Pada prinsipnya undang-undang baru ini berusaha mengembalikan kuasa pertambangan kepada Negara, dalam hal ini pemerintah sehingga pelaksanaan pengusahaan migas juga dikembalikan kepada negara. Konsekuensi dari diberlakukannya UU Migas baik untuk sektor hulu maupun sektor hilir, adalah dibentuknya badan yang khusus mengatur dan melaksanakan kegiatan usaha minyak dan gas. Badan Pelaksana dan Badan Pengatur ini diangkat dan bertanggung jawab kepada presiden. Dalam melaksanakan tugasnya, Badan Pelaksana dan Badan Pengatur dapat membuat kontrak kerja sama dengan badan usaha lain, baik lokal, nasional, maupun internasional. Hal ini tentu saja menghapus semua wewenang yang dimiliki oleh PERTAMINA selama ini. Pada 
sektor hulu pemerintah membentuk Badan Pelaksana Kegiatan Usaha Hulu Minyak Dan Gas (BPMIGAS), sedangkan pada sektor hilir pemerintah membentuk Badan Pelaksana Kegiatan Usaha Hilir Minyak Dan Gas (BPH MIGAS).

Pada November tahun 2012 keluarlah putusan Mahkamah Konstitusi Putusan Nomor 36/Puu-X/2012 atas pengujian terhadap UU Migas, dengan putusan menyatakan Pengaturan mengenai Kelembagaan BP Migas dan menyatakan Pola Kontrak kerjasama (KKS) selama ini dinyatakan inkonstitusional. Lebih lanjut akan dijelaskan dalam pembahasan selanjutnya. Tetapi pasca putusan tersebut maka untuk mencegah kekosongan hukum akibat pembubaran BP Migas mahkamah konstitusi dalam amar putusannya menyatakan Fungsi dan tugas Badan Pelaksana Minyak dan Gas Bumi dilaksanakan oleh Pemerintah, c.q. Kementerian terkait, sampai diundangkannya Undang-Undang yang baru yang mengatur hal tersebut.

Kemudian pemerintah mengeluarkan Peraturan Presiden (Perpres) Nomor 9 Tahun 2013 tentang Penyelenggaraan Pengelolaan Kegiatan Usaha Hulu Minyak dan Gas Bumi. Yang membentuk Satuan Kerja Khusus Pelaksana Kegiatan Usaha Hulu Minyak dan Gas Bumi (SKK Migas) dan bertugas melaksanakan pengelolaan kegiatan usaha hulu minyak dan gas bumi berdasarkan Kontrak Kerja Sama. Pembentukan lembaga ini dimaksudkan supaya pengambilan sumber daya alam minyak dan gas bumi milik negara dapat memberikan manfaat dan penerimaan yang maksimal bagi negara untuk sebesar-besar kemakmuran rakyat. Tetapi SKK Migas hanyalah obat sementara dari masalah hukum yang timbul pasca putusan MK. Perlu revisi UU Migas yang lebih memberikan kepastian dan konstitusionalitas dalam pengelolaan hulu Migas di Indonesia.

Dalam Putusan Nomor 36/Puu-X/2012 yang merujuk putusan Nomor 002/PUU-1/2003, tanggal 21 Desember 2004 mengenai pengujian UU Migas, Mahkamah Konstitusi telah memberi makna mengenai penguasaan negara dalam Pasal 33 UUD NRI 1945, bahwa secara konsepsi penguasaan oleh negara dalam Pasal 33 UUD NRI 1945 memiliki pengertian yang lebih tinggi atau lebih luas daripada pemilikan dalam konsepsi hukum perdata. Konsepsi penguasaan oleh negara merupakan konsepsi hukum publik yang berkaitan dengan prinsip kedaulatan rakyat yang dianut dalam UUD NRI Tahun 1945, baik di bidang politik (demokrasi politik) maupun ekonomi (demokrasi ekonomi). Dalam paham kedaulatan rakyat itu, rakyatlah yang diakui sebagai sumber, pemilik, dan sekaligus pemegang kekuasaan tertinggi dalam kehidupan bernegara, sesuai dengan doktrin "dari rakyat, oleh rakyat, dan untuk rakyat".

Dalam pengertian kekuasaan tertinggi tersebut tercakup pula pengertian pemilikan publik oleh rakyat secara kolektif. Bahwa bumi dan air dan kekayaan alam yang terkandung di dalam wilayah hukum negara pada hakikatnya adalah milik publik seluruh rakyat secara kolektif yang dimandatkan kepada negara untuk menguasainya guna dipergunakan bagi sebesarbesarnya kemakmuran bersama. Karena itu, Pasal 33 ayat (3) menentukan "bumi dan air dan kekayaan alam yang terkandung di dalamnya dikuasai oleh negara dan dipergunakan untuk sebesar-besar kemakmuran rakyat".

Putusan tersebut mempertimbangkan bahwa makna "dikuasai oleh negara" tidak dapat diartikan hanya sebagai hak untuk mengatur, karena hal demikian sudah dengan sendirinya 
melekat dalam fungsi-fungsi negara tanpa harus disebut secara khusus dalam Undang-Undang Dasar. Sekiranya pun Pasal 33 tidak tercantum dalam UUD NRI 1945, kewenangan negara untuk mengatur tetap ada pada negara, bahkan dalam negara yang menganut paham ekonomi liberal sekalipun. Oleh karena itu, dalam putusan tersebut Mahkamah Konstitusi mempertegas pengertian "penguasaan negara" dimaknai rakyat secara kolektif dikonstruksikan oleh UUD NRI 1945 memberikan mandat kepada negara untuk mengadakan:

1. kebijakan (beleid);

2. tindakan pengurusan (bestuursdaad), Fungsi pengurusan (bestuursdaad) oleh negara dilakukan oleh Pemerintah dengan kewenangannya untuk mengeluarkan dan mencabut fasilitas perijinan (vergunning), lisensi (licentie), dan konsesi (consessie);

3. pengaturan (regelendaad), Fungsi pengaturan oleh negara (regelendaad) dilakukan melalui kewenangan legislasi oleh DPR bersama Pemerintah, dan regulasi oleh Pemerintah;

4. pengelolaan (beheersdaad), Fungsi pengelolaan (beheersdaad) dilakukan melalui mekanisme pemilikan saham (share-holding) dan/atau sebagai instrumen kelembagaan, yang melaluinya negara, c.q. Pemerintah, mendayagunakan penguasaannya atas sumber-sumber kekayaan itu untuk digunakan bagi sebesarbesarnya kemakmuran rakyat;

5. pengawasan (toezichthoudensdaad) untuk tujuan sebesar besarnya kemakmuran rakyat. Fungsi pengawasan oleh negara (toezichthoudensdaad) dilakukan oleh Negara, c.q. Pemerintah, dalam rangka mengawasi dan mengendalikan agar pelaksanaan penguasaan oleh negara atas sumber-sumber kekayaan dimaksud benarbenar dilakukan untuk sebesar-besarnya kemakmuran seluruh rakyat.

Kelima bentuk penguasaan negara dalam putusan tersebut yaitu fungsi kebijakan dan pengurusan, pengaturan, pengelolaan dan pengawasan ditempatkan dalam posisi yang sama. Dalam hal Pemerintah melakukan salah satu dari empat fungsi penguasaan negara, misalnya hanya melaksanakan fungsi mengatur, dapat diartikan bahwa negara telah menjalankan penguasaannya atas sumber daya alam. Padahal, fungsi mengatur adalah fungsi negara yang umum di negara mana pun tanpa perlu ada Pasal 33 UUD NRI 1945. Jika dimaknai demikian, makna penguasaan negara tidak mencapai tujuan sebesar-besarnya bagi kemakmuran rakyat sebagaimana maksud Pasal 33 UUD NRI 1945. Dalam rangka mencapai tujuan sebesar-besar kemakmuran rakyat, kelima peranan negara/pemerintah dalam pengertian penguasaan negara tersebut, jika tidak dimaknai sebagai satu kesatuan tindakan, harus dimaknai secara bertingkat berdasarkan efektifitasnya untuk mencapai sebesar-besarnya kemakmuran rakyat. peringkat dari bentuk penguasaan negara yaitu:

Penguasaan negara peringkat pertama, dan yang paling penting adalah negara melakukan pengelolaan secara langsung atas sumber daya alam dalam hal ini Migas. sehingga negara mendapatkan keuntungan yang lebih besar dari pengelolaan sumber daya alam. Hal ini dilakukan Sepanjang negara memiliki kemampuan baik modal, teknologi, dan manajemen dalam mengelola sumber daya alam maka negara harus memilih untuk melakukan pengelolaan secara langsung atas sumber daya alam. Dengan pengelolaan secara langsung, dipastikan seluruh hasil dan keuntungan yang diperoleh akan 
masuk menjadi keuntungan negara yang secara tidak langsung akan membawa manfaat lebih besar bagi rakyat. Pengelolaan langsung yang dimaksud di sini, baik dalam bentuk pengelolaan langsung oleh negara (organ negara) melalui Badan Usaha Milik Negara. Pada sisi lain, jika negara menyerahkan pengelolaan sumber daya alam untuk dikelola oleh perusahaan swasta atau badan hukum lain di luar negara, keuntungan bagi negara akan terbagi sehingga manfaat bagi rakyat juga akan berkurang.Penguasaan negara pada peringkat kedua adalah negara membuat kebijakan dan pengurusan, fungsi negara dalam peringkat ketiga adalah fungsi pengaturan dan pengawasan.

Menurut Mahkamah Konstitusi Pasal 33 UUD NRI 1945 menghendaki bahwa penguasaan negara itu harus berdampak pada sebesarbesar bagi kemakmuran rakyat. Sehingga, "pengertian dikuasai oleh negara" tidak dapat dipisahkan dengan makna untuk "sebesarbesar kemakmuran rakyat" yang menjadi tujuan Pasal 33 UUD NRI Tahun 1945. Hal ini memperoleh landasannya yang lebih kuat dari UUD NRI Tahun 1945 yang dalam Pasal 33 ayat (3) menyatakan, "Bumi dan air dan kekayaan alam yang terkandung di dalamnya dikuasai oleh negara dan dipergunakan untuk sebesarbesar kemakmuran rakyat". Kalimat sebesarbesar kemakmuran rakyat yang akan menjadi ukuran bagi negara dalam menentukan tindakan pengurusan, pengaturan, atau pengelolaan atas bumi, air dan kekayaan alam yang terkandung di dalamnya.

Apabila penguasaan negara tidak dikaitkan secara langsung dan satu kesatuan dengan sebesar-besar kemakmuran rakyat maka dapat memberikan makna konstitusional yang tidak tepat. Artinya, negara sangat mungkin melakukan penguasaan terhadap sumber daya alam secara penuh tetapi tidak memberikan manfaat sebesar-besar kemakmuran rakyat. Di satu sisi negara dapat menunjukkan kedaulatan pada sumber daya alam, namun di sisi lain rakyat tidak serta merta mendapatkan sebesarbesar kemakmuran atas sumber daya alam.

Putusan Mahkamah Konstitusi Nomor 36/PUU-X/2012 juga memfokuskan pada kontrak kerja sama (KKS), dimana UU Migas mengkonstruksikan hubungan antar negara dengan badan usaha yang melakukan pengelolaan Migas dengan hubungan keperdataan dalam bentuk KKS. Menurut UU Migas, KKS adalah Kontrak Bagi Hasil atau bentuk kontrak kerjasama lain dalam kegiatan eksplorasi dan eksploitasi yang lebih menguntungkan dan hasilnya dipergunakan untuk sebesar-besarnya kemakmuran rakyat. Dalam KKS tersebut, BP Migas bertindak mewakili Pemerintah sebagai pihak dalam KKS dengan Badan Usaha atau Bentuk Usaha Tetap yang mengelola Migas.

Dengan posisi tersebut, hubungan antara BP Migas sebagai perwakilan negara dengan Badan Usaha atau Bentuk Usaha Tetap adalah hubungan yang bersifat keperdataan yaitu menempatkan posisi negara dan Badan Usaha atau Bentuk Usaha Tetap yang mengelola Migas dalam posisi yang sederajat. Dalam hal ini ketika kontrak telah ditandatangani, negara menjadi terikat pada isi KKS. Akibatnya, negara kehilangan diskresi untuk membuat regulasi bagi kepentingan rakyat yang bertentangan dengan isi KKS, sehingga negara kehilangan kedaulatannya dalam penguasaan sumber daya alam yaitu kedaulatan untuk mengatur Migas yang bertentangan dengan isi KKS. Padahal menurut mahkamah konstitusi negara sebagai representasi rakyat dalam penguasaan sumber daya alam harus memiliki keleluasaan membuat aturan yang membawa manfaat bagi sebesar- 
besarnya kemakmuran rakyat. Menurut Mahkamah Konstitusi hubungan antara negara dengan swasta dalam pengelolaan sumber daya alam tidak dapat dilakukan dengan hubungan keperdataan, akan tetapi harus merupakan hubungan yang bersifat publik yaitu berupa pemberian konsesi atau perizinan yang sepenuhnya di bawah kontrol dan kekuasaan negara. Kontrak keperdataan akan mendegradasi kedaulatan negara atas sumber daya alam, dalam hal ini Migas.

\section{Alternatif dan Implikasi Model pengelolaan Hulu Migas Kedepan}

Berdasarkan pendapat mahkamah konstitusi tersebut diatas, maka paling tidak terdapat panduan (guidence) konsep pengelolaan Hulu Migas, adapun panduan tersebut adalah sebagai berikut:

Pertama, posisi negara dalam hubungannya dengan sumber daya alam Migas, negara/ pemerintah memiliki keleluasaan membuat regulasi, kebijakan, pengurusan, pengelolaan, dan pengawasan atas sumber daya alam Migas. tidak dibatasi tugas dan kewenangannya pada fungsi pengendalian dan pengawasan semata tetapi juga mempunyai fungsi pengelolaan. pemisahan antara badan yang melakukan fungsi regulasi dan pembuatan kebijakan dengan lembaga yang melakukan pengelolaan dan bisnis Migas secara langsung, mengakibatkan terdegradasinya penguasaan negara atas sumber daya alam Migas.

Kedua, fungsi pengelolaan adalah bentuk penguasaan negara pada peringkat pertama dan paling utama untuk mencapai sebesarbesar kemakmuran rakyat. Pemerintah harus mengutamakan penguasaan negara pada peringkat pertama yaitu melakukan pengelolaan terhadap sumber daya alam
Migas yang membawa kuntungan lebih besar bagi rakyat. Menurut Mahkamah, pengelolaan secara langsung oleh negara atau oleh badan usaha yang dimiliki oleh negara adalah yang dikehendaki oleh Pasal 33 UUD NRI Tahun 1945.

Ketiga, Dalam hal negara tidak memiliki kemampuan atau kekurangan kemampuan baik dalam modal, teknologi dan manajemen untuk mengelola sumber daya alam Migas, maka pengelolaan sumber daya alam dapat diserahkan kepada badan swasta. Pemerintah melakukan tindakan pengurusan atas sumber daya alam Migas dengan memberikan konsesi kepada satu atau beberapa badan usaha milik negara untuk mengelola kegiatan usaha Migas pada sektor hulu. Badan usaha milik negara itulah yang akan melakukan KKS dengan Badan Usaha Milik Daerah, Koperasi, Usaha Kecil, badan hukum swasta, atau Bentuk Usaha Tetap.

Kempat, selain KKS dalam bentuk kontrak bagi hasil, juga dimungkinkan KKS dalam bentuk yang lain, asalkan menguntungkan bagi negara, misalnya yang sekarang ini dikenal yaitu KKS dalam bentuk kontrak jasa. Bentuk KKS selain kontrak bagi hasil adalah tidak bertentangan dengan konstitusi sepanjang memberi manfaat sebesar-besarnya bagi kemakmuran rakyat dan tidak melanggar prinsip penguasaan negara yang dimaksud dalam konstitusi.

Dari guidence tersebut maka Kelembagaan dalam pengelolaan migas paling tidak dapat diformulasikan dengan beberapa alternatif sebagai berikut yaitu:

a. Model Melembagakan SKK Migas secara permanen

Dengan model kelembagaan ini maka SKK Migas akan menjadi perwakilan pemerintah yang khusus mengurus mengenai Pengelolaan Hulu Migas dengan kewenangan menyiapkan kebijakan Mikro 
dan pengawasan dalam pengusahaan hulu migas seperti penentuan Operator dan wilayah kerja (WK), kemudian pelaksana usaha migas diserahkan kepada PT Pertamina sebagai BUMN, selanjutnya SKK Migas juga yang akan menentukan partner PT Pertamina dalam melakukan eksplorasi dan ekspliotasi Migas. Struktur kelembagaan yang ada saat ini tetap dipertahankan, yang perlu diperbaiki adalah memperjelas kewenangan dan fungsi serta memperkuat dasar hukum yang semula berdasarkan Perpres menjadi undang-undang. Pilihan posisi kelembagaan tetap berada dibawah kementerian ESDM yang mempunyai kewenangan membuat kebijakan makro pengelolaan hulu migas, dan juga tetap melakukan pengawasan terhadap SKK Migas dan Pertamina sebagai Operator.

b. Kembali pada model yang memberikan wewenang bagi PERTAMINA.

Model ini menempatkan Pertamina dalam posisi sentral dan strategis yaitu sebagai pelaksana utama kegiatan usaha migas. Undang-Undang No. 8 Tahun 1971 tentang Perusahaan Pertambangan Minyak dan Gas Bumi Negara (UU PERTAMINA), aturan ini memberikan wewenang yang sangat luas bagi PERTAMINA. Dengan model ini, Pemerintah memberikan izin kepada Pertamina untuk melakukan kegiatan pengelolaan hulu migas dengan secara mandiri atau dapat bekerja sama dengan pihak lain. Peran pemerintah adalah mengeluarkan kebijakan, pengaturan, pengusahaan, dan pengawasan. Sedangkan pengelolaan teknis diserahkan pada Pertamina. Dengan kondisi ini Pertamina mempunyai kewenangan dalam pengelolaan, peran kementerian ESDM dalam pengawasan menjadi penting sehingga mekanisme pengawasan tersebut harus dipertegas dalam undang-undang, untuk mencegah kondisi negatif yang dapat timbul dari besarnya peran PERTAMINA tersebut. Selain iti kementerian ESDM menyiapkan kebijakan makro dan mikro dalam pengelolaan hulu Migas.

c. Model Pemerintah secara langsung melakukan penunjukan, dan Mendirikan BUMN baru.

Model seperti ini menempatkan pemerintah melalui kementerian ESDM langsung menentukan kebijakan dan prioritas pengelolaan migas secara makro dan mikro. Tetapi sebagai pelaksana atau operator bukan hanya Pertamina, pemerintah juga membentuk BUMN lain. Dengan konsep pertama, BUMN yang baru tersebut khusus mengerjakan eksplorasi , sehingga Pertamina dikhususkan untuk melakukan eksploitasi. Atau konsep kedua, pemerintah juga mendirikan BUMN yang dapat melaksanakan eksplorasi dan eksploitasi sebagai kompetitor dalam negeri Pertamina atau mengerjakan WK yang sudah ada atau melanjutkan lapangan yang ada, sehingga Pertamina fokus untuk mencari lapangan atau WK yang baru, untuk itu tujuan mendirikan BUMN baru untuk mendorong persaingan kinerja yang lebih baik, pemerintah dapat menentukan apakah WK dikerjakan oleh salah satu BUMN, atau beberapa BUMN, atau BUMN bekerjasama dengan swasta. Tetapi memang harus dipikirkan modal yang besar untuk mendirikan BUMN baru yang akan bergerak dalam bisnis Migas ini.

d. Model Pembentukan Lembaga Baru

Model ini yaitu pembentukan lembaga baru ini, Pemerintah dan DPR melalui UU 
Migas baru membentuk lembaga baru yang bertindak sebagai lembaga baru yang khusus melakukan regulasi, kebijakan, pengurusan, pengelolaan, dan pengawasan Pengelolaan Migas, dengan kedudukan untuk mewakili negara dalam menjalankan peran fungsifungsi penguasaan negara atas migas. Kelebihan model ini adalah kelembagaan baru ini akan membangun sistem yang lebih tertata belajar dari kelembagaan yang ada sebelumnya, kelembagaan ini didelegasikan oleh undang undang. Tetapi membutuhkan waktu yang agak lama dalam melakukan penataan lembaga dan penataan organisasi. dalam pelaksanaannya kelembagaan inilah yang akan bertanggung jawab secara penuh terhadap pengelolaan migas dan menentukan prioritas pengelolaan yang dapat dilaksanakan oleh Pertamina atau swasta.

Alternatif Model pengelolaan tersebut diatas merupakan cerminan dari pelaksanaan pengelolaan hulu migas berdasarkan putusnan Mahkamah konstitusi. Dimana peran negara atau pemerintah dalam regulasi, kebijakan, pengurusan, pengelolaan, dan pengawasan dalam pengelolaan Hulu migas yang harus memberikan keuntungan sebesar besarnya pada rakyat.

\section{E. Penutup}

Berdasarkan pembahasan diatas maka dapat di simpulkan, bahwa pengelolaan hulu migas tidak dapat dilepaskan dari tujuan negara dan arah pengelolaan negara yaitu untuk mencapai kesejahteraan dan keadilan sosial, sehingga secara konstitusional menjadi perhatian penting dalam pembangunan nasional, posisi negara dalam hubungannya dengan sumber daya alam
Migas, negara/pemerintah memiliki keleluasaan membuat regulasi, kebijakan, pengurusan, pengelolaan, dan pengawasan atas sumber daya alam Migas. Fungsi pengelolaan adalah bentuk penguasaan negara pada peringkat pertama dan paling utama untuk mencapai sebesar-besar kemakmuran rakyat. Pemerintah harus mengutamakan penguasaan negara pada peringkat pertama yaitu melakukan pengelolaan terhadap sumber daya alam Migas yang membawa kuntungan lebih besar bagi rakyat. Dalam hal negara tidak memiliki kemampuan atau kekurangan kemampuan baik dalam modal, teknologi dan manajemen untuk mengelola sumber daya alam Migas, maka pengelolaan sumber daya alam dapat diserahkan kepada badan swasta.

Paling tidak terdapat 4 (empat) alternatif model kelembagaan pengelolaan Hulu Migas yaitu: pertama, Model Melembagakan SKKMigas secara permanen. Kedua, Kembali pada model yang memberikan wewenang bagi Pertamina. Ketiga, Model Pemerintah secara langsung melakukan penunjukan, dan Mendirikan BUMN baru. Keempat, Model Pembentukan Lembaga Baru.

Dari uraian diatas terdapat beberpa saran yang bisa dilakukan oleh pemerintah. Pertama, Pemerintah dan DPR harus menjadikan putusan mahkamah konstitusi sebagai bahan acuan dalam mendesain model pengelolaan Hulu Migas, sehingga dalam revisi UU Migas, dapat menghasilkan kelembagaan dan pengelolaan yang konstitusional.Kedua,Pemerintah dan DPR segera menyelesikan Revisi UU Migas dalam rangka menbangun kepastian berinvestasi dalam bisnis Migas di Indonesia, dengan adanya kepastian hukum maka akan meningkatkan iklim investasi dibidang hulu migas. 


\section{Daftar Pustaka}

\section{Buku}

Abdul Nasir, Sejarah Sistem Fiskal Migas Indonesia, (Jakarta: Grasindo, 2014)

Afifah Kusumadara, Kontrak Bisnis Internasional, (Jakarta: Sinar Grafika, 2013)

Badan Pembinaan Hukum Nasional, Perencanaan Pembangunan Hukum Nasional 2015-2019, (Jakarta: Pusat Perencanaan Pembangunan Hukum Nasional, 2012)

Benny Lubiantara, Ekonomi Migas Tinjauan Aspek Komersial Kontrak Migas, (Jakarta: Gramedia Widiasarana Indonesia, 2012)

C.F.G. Sunaryati Hartono, Penelitian Hukum Di Indonesia Pada Akhir Abad Ke-20, (Bandung: Alumni, 1994)

Daniel Johnston, International Potreleum fiscal system and production Sharing Contract, (Oklahoma: Price Waterhouse Publishing, 1994)

Juli Panglima Saragih, Sejarah Perminyakandi Indonesia, Cetakan I (Jakarta: CV. Aghrindo Abadi, 2010)

M. Kholid Syeirazi, DiBawah Bendera Asing; Liberalisasi Industri Migas di Indonesia, Cetakan pertama, (Jakarta: penerbit Pustaka LP3S Indonesia, 2009)

Mahfud.M.D., Politik Hukum di Indonesia, edisi revisi. Cetakan pertama, (Jakarta: Rajawali Pers, 2009)

Ronny Hanitijo Soemitro, Metodologi Penelitian Hukum dan Jurimetri, Cetakan Kelima, (Jakarta: Ghalia Indonesia, 1994)

Rudi M. Simamora, Hukum Minyak dan Gas Bumi, (Jakarta: Jambatan, 2000)

Salim H. S, Hukum Pertambangan di Indonesia, (Jakarta: Rajagrafindo Persada, 2006)

SKK Migas, Laporan Tahunan 2014, (Jakarta: SKK Migas, 2014)
Soerjono Soekanto \& Sri Mamudji, Penelitian Hukum Normatif: Suatu Tinjauan Singkat, (Jakarta: Rajawali Pers, 2001)

Soetandyo Wignjosoebroto, Hukum, Paradigma Metode dan Dinamika Masalahnya, (Jakarta:Elsam dan Huma, 2002)

\section{Makalah/Artikel/Prosiding/Hasil Penelitian}

Hamdan Zoelva, "Kewenangan Mahkamah Konstitusi Dalam Constitutional Complaint dan Constitutional Question," Makalah disampaikan pada acara Dialog Akademik Program Pasca Sarjana Fakultas Hukum Universitas Hasanuddin, Mahkamah Konstitusi Republik Indonesia, (8 November 2010)

\section{Internet}

http://www.skkmigas.go.id/data-dan-fakta-seputarblok-mahakam, (diakses 9 Juni 2015)

http://www.pushep.or.id/view_publikasi. php?id=12\#.VX0wI5Nq9_k.Kepastian Hukum Terhadap Kontrak Blok-Blok Migas yang Akan Berakhir, (diakses 9 Juni 2015)

\section{Peraturan}

Undang-Undang Dasar Negara Republik Indonesia Tahun 1945

Undang-Undang Nomor 22 Tahun 2001 tentang Minyak dan Gas Bumi

Undang-Undang Nomor 8 Tahun 1971 tentang Perusahaan Pertambangan Minyak dan Gas Bumi Negara

Putusan Mahkamah Konstitusi Nomor 36/ PUU-X/2012 pengujian atas Undang-Undan gNomor 22 Tahun 2001 tentang Minyak dan Gas Bumi

Peraturan Presiden Nomor 9 Tahun 2013 tentang Penyelenggaraan Pengelolaan Kegiatan Usaha Hulu Minyak dan Gas Bumi 